ACTA MYCOLOGICA

Vol. 41 (1): 155-164

2006
Dedicated to Professor Alina Skirgietto

on the occasion of her ninety fifth birthday

\title{
A contribution to the lichen biota of Belarus
}

\author{
VLADIMIR V. GOLUBKOV ${ }^{1}$ and MARTIN KUKWA ${ }^{2}$ \\ ${ }^{1}$ Department of Botany, Ya Kupala Hrodna State University \\ Azheshka 22, BY 230023 Hrodna, vgolubkov@grsu.by \\ ${ }^{2}$ Department of Plant Taxonomy and Nature Protection, University of Gdańsk \\ Al. Legionów 9, PL 80441 Gdańsk, dokmak@univ.gda.pl
}

Golubk ov V.V., Ku kw a M.: A contribution to the lichen biota of Belarus. Acta Mycol. 42 (1): 155 164, 2006.

Details of 11 lichen and 1 lichenicolous fungus taxa occurring in Belarus are presented, of which 6 lichens (Cliostomum leprosum, Fellhanera gyrophorica, Lecanora thysanophora, Lepraria eburnea, L.jackii, L.neglecta) and 1 lichenicolous fungus (Tremella hypogymniae) are newly reported for the country; new localities of recently reported Lepraria elobata and $L$. incana s.str. are presented and the occurrence of Chrysothrix candelaris, Loxospora elatina and Pertusaria coronata is confirmed. The taxonomy of Chrysothrix candelaris is briefly discussed and localities of Cliostomum leprosum from Poland are reported.

Key words: sorediate lichens, lichenicolous fungus, new species, Eastern Europe

\section{INTRODUCTION}

The lichen biota in Central and East-Central Europe is reasonably well studied; however, in many regions some groups of species are still very poorly known, particularly the sorediate crustose lichens and lichenicolous fungi which have been neglected in the past. Other groups have also been under-recorded, as well as many taxa not recognized until recently, even though some were common constituents of the biota. This paper contributes to our knowledge of the Belarussian lichen biota by reporting some new or noteworthy taxa belonging mainly to the commonly or constantly sterile sorediate lichens, as well as the lichenicolous fungus, Tremella hypogymniae.

\section{MATERIAL AND METHODS}

The lichen collection of V.V. Golubkov has been studied, including chemical analyses using thin layer chromatography (TLC) according to the methods proposed by Orange et al. (2001). For each taxon, notes are provided on their characteristics 
and similar species are discussed; general distribution details are provided for taxa new to Belarus. The lichenicolous fungus is marked with an asterisk $(*)$.

\section{LIST OF SPECIES}

\section{Chrysothrix candelaris (L.) J.R. Laundon}

This species is rather widespread in Europe, but its chemistry has only been studied in some countries (Laundon 1981; Tønsberg 1992), and in Central and Central-Eastern Europe the chemical variability has never been studied. Our specimens contain pinastric acid and according to Tønsberg (1992) belong to chemotype 1 . However, Kalb (2001), who revised the concept of $C$. candelaris, recognized tropical entities with pinastric acid as a separate species, C. xanthina (Vain.) Kalb. This taxon had been considered to be only a synonym of $C$. candelaris (Laundon 1981), but Kalb found, in addition to chemistry, some differences in anatomy, distribution and ecology, and pointed out that the pinastric acid containing samples of $C$. candelaris s.l. from temperate regions may represent an as yet undescribed taxon. As there are no differences between specimens containing calycin (C. candelaris s.str.) and pinastric acid (suggested undescribed species) in temperate regions, we propose here to include them in C. candelaris, at least temporarily. However, this problem needs further studies based on molecular analyses.

SpeCimens EXAmined: Belarus, Brestskaya oblast', Kamenetskiï region, Belovezhskaya Pushcha (Forest), forest section No 741, oak forest, on trunk of oak, 20.07.1973, leg. D.I. Tret'yakov; Brestskaya oblast', Pruzhanskiï region, Belovezhskaya Pushcha, forest section No 589, vicinity of Pererevo, oak forest with hornbeam near river, on trunk of maple, 22.06.1983, leg. V.V. Golubkov.

Cliostomum leprosum (Räsänen) Holien \& Tønsberg

This species is new to the country. It is a rare lichen taxon in Europe and has been reported from Finland (S a ntess on et al. 2004), Norway, Sweden (Tøn sberg 1992; Santesson et al. 2004), Poland (Fałtynowicz 2003) and Switzerland (Dietrich, Scheidegger 1996). Details of Polish localities have never been published until know (see additional specimens examined).

C. leprosum is characterised by the sorediate whitish-grey thallus producing atranorin and caperatic acid, very rarely accompanied by an unidentified fatty acid (Tønsberg 1992). All specimens from Belarus and Poland contained atranorin and caperatic acid, but the additional fatty acid was detected in specimen from 'Mechacz' nature reserve.

The species can be mistaken for some Ochrolechia species with a whitish thallus and not delimited soralia, especially $O$. microstictoides Räsänen. However only $C$. leprosum produces atranorin with caperatic acid (Tønsberg 1992).

SPECIMENS EXAMINED: Belarus, Minskaya oblast', Myadel'skiï region, exact locality unknown, old railway, pine forest, on bark of pine, 14.06.1984, leg. V.V. Golubkov.

Additional specimens EXamined: Poland, Romincka Forest, N part of the 'Mechacz' nature reserve, ATPOL grid square Af85, on bark of pine, 17.05.1985, leg. S. Cieśliński \& Z. Tobolewski (KTC, duplicate in BG and UGDA-L); Bielska Plain, Białowieża Forest, 'Michnówka' nature reserve, forest section No 572; ATPOL grid square Cg64, on bark of pine in peat bog pine forest, 11.08.2002, leg. P. Czarnota 
(GPN 2984, duplicate in UGDA-L); Augustowska Plain, Augustowska Forest, Wigierski National Park, forest section No 159n; ATPOL grid square Bf29, on bark of pine in peat bog pine forest, 08.11.1997, leg. W. Faltynowicz (WRSL, duplicate in UGDA-L 9329).

Fellhanera gyrophorica Sérus., Coppins, Diederich \& Scheid.

This species is new to the country. Only recently it has been described from Austria, Lithuania, Luxembourg, Poland, Switzerland and Ukraine (Sérusiaux et al. 2001). Additionally it has been found in Estonia (Motiejūnaitè, PrigodinaLukošiene 2002) and Lithuania (Motiejūnaitè et al. 2003), and further localities were discovered in Poland (Czyżewska et al. 2001, 2002, 2005; Sparrius 2002).

When described, F. gyrophorica was known only from sterile collections with pycnidia (Sérusia ux et al. 2001). Apothecia were discovered in the same year in material collected in Poland (Sparrius 2001) and fertile material has also been reported from Lithuania (Motiej ū naitè et al. 2003). The specimen from Belarus possesses only pycnidia.

F. gyrophorica is usually sterile and easily recognisable by its rather large brown pycnidia reacting $\mathrm{C}+$ red and pyriform conidia. Some Bacidia s.lat. and Micarea species can look similar, but they can be easily separated by the pycnidial characters (Sérusiaux et al. 2001).

SPecimen EXAmined: Belarus, Brestskaya oblast', Pruzhanskii region, $3 \mathrm{~km}$ W of Babinec village, Belovezhskaya Pushcha, forest section No 560A, on bark of black alder, 26.07.1983, leg. V.V. Golubkov.

\section{Lecanora thysanophora R.C. Harris}

This species is new to Belarus. It was described from North America (Ha r r is et al. 2000), and than reported from many European countries (Tønsberg 1999; Print zen et al. 2002; Kowalewska, Kukwa 2003; Motiejūnaitè et al. 2003; Guttová, Palice 2004; Mrak et al. 2004; Czyżewska et al. 2005; Ku kwa 2005).

L. thysanophora is a sorediate lichen producing a characteristic fibrillose prothallus which is well developed in at least some part(s) of the thallus. It always contains atranorin, usnic acid, zeorin and terpenoids called 'thysanophora unknowns' (Har ris et al. 2000). Some North American specimens also produce porphyrillic acid (Ha r ris et al. 2000); however, no porphyrillic acid has been detected in European specimens to date (Ku kwa, unpubl.).

The species can be very easily mistaken for Haematomma ochrolecum (Neck.) J.R. Laundon; however, they can be separated by their chemistry since L. thysanophora produces 'thysanophora unknowns' which are not present in H. ochrolecum (Harris et al. 1999). When the fibrillose prothallus is not well developed, L. thysanophora can remind one of L. expallens Ach., but L. thysanophora contains atranorin and 'thysanophora unknowns', whereas L. expallens contains xanthones in addition to usnic acid and zeorin (Tønsberg 1992; Harris et al. 1999).

SPECIMENS EXAMINED: Belarus, Gomel'ckaya oblast', Mozyrskiï region, vicinity of Proftyuki village, oak forest, on oak, 26.08.1977, leg. V.V. Golubkov; Gomel'ckaya oblast', Mozyrskiï region, vicinity of Simonovichskiï Mlynok village, Pripyatskiï National Park, spruce forest, on bark of black alder, 16.08.1982, leg. V.V. Golubkov; Grodnenskaya oblast', Novogrudskiï region, forest section No. 56, oak forest with 
spruce and hornbeam, on bark of hornbeam, 24.06.1987, leg. V.V. Golubkov; Grodnenskaya oblast', Svislochskiï region, Belovezhskaya Pushcha, forest section No 82, lime tree forest, on bark of lime tree, 17.06.1983, leg. V.V. Golubkov; Brestskaya oblast', Pruzhanskiï region, $3 \mathrm{~km}$ W of Babinec village, Belovezhskaya Pushcha, forest section No 560A, on black alder, 26.07.1983, leg. V.V. Golubkov.

\section{Lepraria eburnea J.R. Laundon}

This species is new to Belarus. It is rather widespread in Europe (e.g. Laundon 1992; Tønsberg 1992; Orange 1997; Kukwa 2002a; Bayerová, Kukwa 2003), and rarely reported in North America (Laundon 1992; Orange 1997), Asia (Güvenç, Oztürk 1999; Cobanoglu, Akdemir 2000) and Oceania (New Zealand) (Wirth 1997).

L. eburnea is well characterised by its leprose thallus consisting of soredia producing some projecting hyphae and the presence of alectorialic acid (usually barbatic acid is also detectable). Commonly alectorialic acid is accompanied by protocetraric acid (chemotype I), very rarely with psoromic acid (chemotype III; known only from Great Britain), but also quite commonly it occurs alone (chemotype II) (Orange 1997; see also La und on 1992 and Tønsberg 1992). Sometimes it is very difficult to determine the chemotype, since the additional substances may occur in very low concentrations. The Belarusian specimen probably belongs to chemotype I, as the habitat is more suitable for it (see Kukwa 2002a); however, further studies with more sensitive methods should be carried out to solve its identity.

Chemically, L. eburnea can be mistaken only for L. neglecta (Nyl.) Erichsen, as both produce alectorialic acid. However, the morphology and habitat requirements are different: L. eburnea has a leprose thallus and occurs on rather shaded habitats protected from direct rain, whereas $L$. neglecta has a granular course thallus and grows in places exposed to sun and rain (e.g. Laundon 1992; Tønsberg 1992; Kukwa 2002a). Some species, such as L. incana (L.) Ach. and L. lobificans Nyl., have a similar morphology, but they do not produce alectorialic acid (cf. La und on 1992; Tønsberg 1992).

SPECIMEN EXAMINED: Belarus, Brestskaya oblast', Kamenetskiï region, vicinity of Kamenyuki village, Belovezhskaya Pushcha, forest section No 778, oak forest, on decaying oak, 17.07.1983, leg. V.V. Golubkov.

\section{Lepraria elobata Tønsberg}

This species has been only recently reported from Belarus by Czyżewska $\& \mathrm{Ku} \mathrm{kwa} \mathrm{(2005).} \mathrm{Although} \mathrm{known} \mathrm{from} \mathrm{only} \mathrm{four} \mathrm{collections,} \mathrm{it} \mathrm{is} \mathrm{probably} \mathrm{a} \mathrm{com-}$ mon species, as it is in neighbouring Poland (Ku kw a 2002a, b).

The species is characterised by the predominantly grey thallus, the absence of a medulla, soredia with a well developed wall and lacking projecting hyphae, and the presence of atranorin, zeorin and stictic acid complex (Tønsberg 1992). L. lobificans is identical in its chemistry, but differs by its usually greenish woolly thallus and airy soredia, in many cases with highly visible long projecting hyphae (Tønsberg 1992). L. elobata can be mistaken for L. incana, but it is easily separated by the chemistry, as it produces divaricatic acid and zeorin (Tønsberg 1992).

SPECimENS EXAMINED: Belarus, Minskaya oblast', Minskiï region, $1.5 \mathrm{~km}$ N Slabodshchina village, on bark of pine, 25.04.1976, leg. G.N. Antonov \& O.M. Maclovskï; Minskaya oblast', Minskiï region, $2.3 \mathrm{~km}$ N of Slabodshchina village, on bark of pine, 
25.04.1976, leg. O.M. Maclovskï; Vitebskaya oblast', Berezinckiï nature reserve, 0.1 km NE of 'Gurba' range, on bark of oak, 16.08.1973, leg. Luk'yanov.

Lepraria incana (L.) Ach.

The first Belarusian record was recently confirmed by TLC (Czyżews ka, Ku kwa 2005). The species is probably very common, as it is, for example, in neighbouring Poland (Kukwa 2002a).

L. incana is well characterized by the production of divaricatic acid and zeorin (e.g. Tønsberg 1992). The only other European taxon with divaricatic acid and zeorin, L. crassissima (Hue) Lettau, differs in its production of large amounts of nordivaricatic acid, which is only present in traces in L. incana (B o o m et al. 1994). SPECIMENS EXAMINED: Belarus, Grodnenskaya oblast', Novogrudskiï region, $2 \mathrm{~km}$ E of Vcelyubci, on mossy decaying log, 23.08.1981, leg. O.M. Maclovskï̈; Brestskaya oblast', Belovezhskaya Pushcha, forest section No 824, on bark of black alder, 16.06.1983, leg. V.V. Golubkov; Brestskaya oblast', Belovezhskaya Pushcha, forest section No 98, spruce forest, on bark of spruce, 16.06.1983, leg. V.V. Golubkov; Brestskaya oblast', Belovezhskaya Pushcha, forest section No 824, peat bog pine forest, on decaying wood, 10.08.1986, leg. V.V. Golubkov; Brestskaya oblast', Kamenetskii region, vicinity of Kamenyuki village, Belovezhskaya Pushcha, forest section 829, oak forest with hornbeam, on oak, 17.07.1983, leg. V.V. Golubkov; Brestskaya oblast', Kamenetskiï region, $5 \mathrm{~km}$ E of Pashuki village, Belovezhskaya Pushcha, forest section No 890b, oak forest, in the crevices of tree bark 28.07.1983, leg. V.V. Golubkov; Grodnenskaya oblast', Svislochskiï region, Belovezhskaya Pushcha, forest section No 82, lime tree forest, on decaying spruce log, 17.08.1982, leg. V.V. Golubkov; Gomel'ckaya oblast', Mozyrskiï region, vicinity of Cumonovichckiï Mlynok village, Pripyatskiï National Park, spruce forest, on bark of spruce, 15.08.1982, leg. V.V. Golubkov.

\section{Lepraria jackii Tønsberg}

This species is new to Belarus. It is rather widespread in Europe (e.g. Kü mmer ling et al. 1995; Kukwa 2002a; Bayerová, Kukwa 2003), and is also reported from Asia, Australia and North America (Kümmerling et al. 1995). L. jackii prefers bark of coniferous trees, and according to Kümmerling et al. (1995) it has widened its distribution due to the preference of such trees in forest management. It also commonly occurs on birches, and can be more widely distributed because of the popularity of planting such trees (Kukwa, unpubl.).

L. jackii is characterised by the powdery, green-grey thallus containing atranorin, jackinic (very rarely absent) and roccellic (usually present) acids (Tøn sberg 1992; Leuckert et al. 1995). The most similar chemistry is known from L. borealis Lohtander \& Tønsberg, but this species has a granular thallus and prefers exposed to rain habitats, whereas L. jackii has a powdery thallus and grows on substrata sheltered from direct rain (e.g. Loht ander 1994). L. rigidula (de Lesd.) Tønsberg and L. toensbergiana Bayerová \& Kukwa also produce atranorin and fatty acids, but they also produce nephrosteranic and toensbergianic acids, respectively (Le uckert et al. 1995; Baye rová et al. 2005)

Specimens EXAMINED: Brestskaya oblast', Kamenetskiï region, vicinity of Kamenyuki village, Belovezhskaya Pushcha, forest section No 582/601, on bark of pine, 08.08.1983, leg. V.V. Golubkov; Grodnenskaya oblast', Novogrudskiï region, vicinity of Novogrudok village, on bark of spruce, 06.06.1989, leg. V.V. Golubkov; Minskaya 
oblast', Minskiï region, $2 \mathrm{~km} \mathrm{~N}$ of Slabodshchina village, pine forest, on bark of pine, 03.10.1976, leg. G.N. Antonov \& O.M. Maclovskï̈; Vitebskaya oblast', Polotskiï region, near lake Glubokoe, pine forest, on deacying wood, 20.07.1985, leg. V.V. Golubkov.

Lepraria neglecta (Nyl.) Erichsen

This species is new to Belarus. It is a cosmopolitan lichen known from Europe (e.g. Laundon 1992; Tønsberg 1992; Kümmerling et al. 1993; Motiejūnaitè 1999; Ku kw a 2002a), Asia (Kü m me rling et al. 1993; Aptroot and Seaward 1999), Australia (Kümmerling et al. 1993), North America (Kü m mer ling et al. 1993) and Antarctica (Olech 2001).

Morphologically L. neglecta resembles other species of the so-called L. neglecta group: L. borealis Lohtander \& Tønsberg, L. cacuminum (A. Massal.) Lohtander and $L$. caesioalba (de Lesd.) J.R. Laundon. However, it can be very easily distinguished by the chemistry, as it is the only species producing alectorialic acid as a major compound (e.g. Tønsberg 1992; Loh tander 1994; Le u ckert et al 1995). Chemically $L$. neglecta is very similar to L. eburnea, but the morphology easily separates these two taxa (for differences, see under that species).

SPECIMEN EXAMINED: Belarus, Vitebskaya oblast', Glubokskiï region, border of lake Dolgoe, on stone, 11.05.1985, leg. V.V. Golubkov.

Loxospora elatina (Ach.) A. Massal.

This species has been reported from Belarus by Tomin (1956) and Gorbach (1973), but these identifications were based only on spot test reactions. The present record is the first one confirmed by TLC.

L. elatina is characterized by its greyish areolate thallus with at least at the beginning discrete soralia. It produces thamnolic acid and \pm elatinic acid (Schreiner and Hafellner 1992; Tønsberg 1992). It can be mistaken for some Ochrolechia species, but it differs in its chemical constituents.

SPECIMEN EXAMINED: Belarus, Vitebskaya oblast', Verkhodvinskiï region, no detailed locality, on birch, 20.06.1986, leg. V.V. Golubkov.

Pertusaria coronata (Ach.) Th. Fr.

This species has been reported from Belarus by Tomin (1956), Gorbach (1973) and Golubkov (1987), but the record below is the first one confirmed by TLC.

There are only two other isidiate Pertusaria species which can be mistaken for $P$. coronata, namely P. coccodes (Ach.) Nyl. and P. flavida (DC.) J.R. Laundon. However, these species have very distinctive chemistry. $P$. coronata produces coronaton and stictic acid complex which gives a $\mathrm{P}+$ orange reaction of the thallus, $P$. coccodes has norstictic acid which gives a $\mathrm{K}+$ yellow changing to red reaction, and P. flavida posses xanthones, which gives a C+ orange reaction (cf. Tøn sberg 1992).

SPECIMEN EXAMINED: Belarus, Grodnenskaya oblast', Svislochskiï region, Belovezhskaya Pushcha, forest section No 82, lime tree forest, on lime tree, 17.06.1983, leg. V.V. Golubkov.

*Tremella hypogymniae Diederich \& M.S. Christ.

This lichenicolous fungus is new to Belarus. It is rather widespread in Europe (Die derich 1996; Czyżewska et al. 2001, 2002; Kukwa et al. 2002; Czyżewska 2003; Ku kwa 2004), and also known from North America (Die derich 1996). 
This species, belonging to the Heterobasidiomycetes, induces the formation of convex, pale to pinkish, sometimes dark or black, galls on the thalli of Hypogymnia physodes (L.) Nyl. (Diederich 1996).

SPECIMEn EXAmined: Belarus, Grodnenskaya oblast', Svislochskiï region, Belovezhskaya Pushcha, forest section No 82, lime tree forest, on thallus of Hypogymnia physodes growing on lime tree, 17.06.1983, leg. V.V. Golubkov.

Acknowledgements. We are very grateful to Professor Krystyna Czyżewska (University of Łódź) for her valuable help during the preparation of the paper and Professor Mark R.D. Seaward (University of Brad ford) for checking the English. We would like to thank also Professor Stanisław Cieśliński (Świętokrzyska Academy), Dr. Paweł Czarnota (Gorce National Park) and Professor Wiesław Fałtynowicz (University of Wrocław) for making available their specimens of Cliostomum leprosum.

\section{REFERENCES}

Aptroot A., Seaward M.R.D. 1999. Annotated checklist of Hongkong lichens. Trop. Bryology 17: 57101.

Bayerová Š., Kukwa M. 2003. New records of leprarioid lichens in the Czech Republic. Biologia, Bratislava 59: 1923.

Bayerová Š., Kukwa M., Fehrer J. 2005. A new species of Lepraria (lichenized Ascomycetes) from Europe. Bryologist 108: 131138.

Boom P.P.G. van den, Brand M., Diederich P., Aptroot A., Sérusiaux E. 1994. Re port of lichenological field meeting in Luxembourg. Bull. Socc. Nat. luxemb. 95: 145176.

Cobanoglu G., Akdemir B. 2000. New records for Turkish lichen flora. In: The fourth IAL Sym posium Progress and Problems in Lichenology at the Turn of the Millenium, Barcelona, 38 Septem ber 2000. Book of abstracts, p. 92.

Czyżewska K. 2003. Distribution of some lichenicolous fungi in Poland. Acta Mycol. 38 (1/2): 111 122.

Czyżewska K., Cieśliński S., Motiejūnaitė J., Kolanko K. 2002. The Budzisk nature reserve as a biocentre of lichen diversity in Knyszyńska Large Forest (NE Poland). Acta Mycol. 37 (1/2): 7792.

Czyżewska K., Kukwa M. 2005. Notes on two species of Lepraria from Belarus. Graphis Scripta 17: 2021.

Czyżewska K., Motiejūnaitė J., Cieśliński S. 2001. Species of lichenized and allied fungi new to Bialowieża Large Forest (NE Poland). Acta Mycol. 36 (1): 1319.

Czyżewska K., Motiejūnaitė J., Cieśliński S. 2005. New and noteworthy species of lichens and allied fungi from North Eastern Poland. Acta Mycol. 40 (2): 277291.

Diederich P. 1996. The lichenicolous Heterobasidiomycetes. Biblioth. Lichenol. 61: 1198.

Dietrich M., Scheidegger C. 1996. The importance of sorediate crustose lichens in the epiphytic lichen flora of the Swiss Plateau and the Pre Alps. Lichenologist 28: 245256.

Fałtynowicz W. 2003. The lichens, lichenicolous and allied fungi of Poland an annotated checklist. (In:) Z. Mirek (eds), Biodiversity of Poland 6. W. Szafer Institute of Botany, Polish Academy of Sciences, Kraków, 435 pp.

Golubkov V.V. 1987. Vidovoï sostav i struktura likhenoflory gosudarstvennoho zapovedno okhotnich'eho khoziaïstva 'Belovezhskaya pushcha'. Chast' 1. Vidovoï sostav i struktura likheno flory 'Belovezhskoï pushchi': anot. spisok. Manuscript (deposited at VINITI 22.04.87, deposition No 2829 B87), 96 pp.

Gorbach N.W. 1973. Lishaïniki Belarusi. Opredelitel'. Nauka i tekhnika, Minsk, 583 pp.

Gut tová A., Palice Z. 2004. Lišajníki Národného Parku Muránska planina III Cigánka. [Lichens of Muránska Planina National Park III Cigánka]. Reussia 1, Suppl. 1: 1147.

Güvenç Ş., Oztürk Ş. 1999. Lichens in the North East regions of Cyprus. Feddes Repert. 110: 455463.

Harris R.C., Brodo I.M., Tønsberg T. 2000 (2001). Lecanora thysanophora, a common leprose lichen in North America. Bryologist 103: 790793.

Kalb K. 2001. New or otherwise interesting lichens. I. Biblioth. Lichenol. 78: 141167. 
Kowalewska A., Kukwa M. 2003. Additions to the Polish lichen flora. Graphis Scripta 14: 1117. Ku kwa M. 2002a. Lepraria Ach. and Leproloma Cromb. in Poland. Biblioth. Lichenol. 82: 6776.

Ku kwa M. 2002b. Porosty z rodzajów Lepraria i Leproloma w Puszczy Białowieskiej. Parki Nar. Rez. Przyr. 21: 253262.

Ku kw a M. 2004. New or interesting records of lichenicolous fungi from Poland II. Species mainly from northern Poland. Herzogia 17: 6775.

Ku kw a M. 2005. Lecanora thysanophora (Lecanoraceae, zlichenizowane Ascomycota)w Polsce. Fragm. Flor. Geobot. Polonica 12: 385391.

Kukwa M., Motiejūnaitė, J., Rutkowski, P., Zalewska, A. 2002. New or interesting records of lichenicolous fungi from Poland I. Herzogia 15: 129139.

Kümmerling H., Leuckert C., Wirth V. 1991. Chemische Flechtenanalysen VI. Lepraria in cana (L.) Ach. Nova Hedwigia 53: 507517.

Kümmerling H., Triebel D., Rambold G. 1993. Lepraria neglecta and its lichenicolous fungi. Bilbioth. Lichenol. 53: 147160.

Kümmerling H., Leuckert C., Wirth V. 1995. Chemische Flechtenanalysen XI. Lepraria jackii Tønsberg. Nova Hedwigia 60: 457465.

Laund on J.R. 1981. The species of Chrysothrix. Lichenologist 13:101 121.

Laund on J.R. 1992. Lepraria in the British Isles. Lichenologist 24: 315350.

Leuckert C., Kümmerling H., Wirth V. 1995. Chemotaxonomy of Lepraria Ach. and Leprolo $m a$ Nyl ex. Crombie, with particular reference to Central Europe. Biblioth. Lichenol. 58: 245259.

Loht ander K. 1994. The genus Lepraria in Finland. Ann. Bot. Fenn. 31: 223231.

Motiejūnaitè J. 1999. Checklist of lichens and allied fungi of Lithuania. Botanica Lithuanica 5: 251269.

Motiejūnaitè J., Prigodina Lukosiene I. 2002. Chaenothecopsis rubescens new to Lithuania and Fellhanera gyrophorica new to Estonia. Graphis Scripta 13: 4344.

Motiejūnaite J., Kukwa M., Czarnota P., Prigodina Lukošienè I., Himelbrant D., Kuznetsova E., Kowalewska A. 2003. Lichens and allied fungi collected during the 15th symposium of Baltic mycologists and lichenologists in Birštonas, Lithuania. Botanica Lithu anica 9: 109119.

Mrak T., Mayrhofer H., Batič F. 2004. Contributions to the lichen flora of Slovenia XI. Lichens from the vicinity of Lake Bohinj (Julian Alps). Herzogia 17: 107127.

Ole ch M. 2001. Annotated checklist of Antarctic lichens and lichenicolous fungi. Institute of Botany of Jagiellonian University, Kraków, 145 pp.

Orange A. 1997. Chemical variation in Lepraria eburnea. Lichenologist 29: 913.

Printzen C., Halda J., Palice Z., Tønsberg T. 2002. New and interesting lichen records from old growth forest stands in the German National Park Bayerischer Wald. Nova Hedwigia 74: 2549.

Santesson R., Moberg R., Nordin A., Tønsberg T., Vitikainen O. 2004. Lichen form ing and lichenicolous fungi of Fennoscandia. Museum of Evolution, Uppsala University, Uppsala, $359 \mathrm{pp}$.

Schreiner E., Hafellner J. 1992. Sorediöse, corticole Krustenflechten im Ostalpenrum. I. Die Flechtenstoffe und die gesicherte Verbreitung der besser bekannten Arten. Biblioth. Lichenol. 45: 1291.

Sérusiaux E., Coppins B.J., Diederich P., Scheidegger C. 2001. Fellhanera gyrophorica, a new Europaean species with conspicuous pycnidia. Lichenologist 33: 285289.

Sparrius L.B. 2002. Discovery of apothecia confirms generic position of Fellhanera gyrophorica. Li chenologist 34: 86.

To m in M.P. 1956. Opredelitel' korkovych lishaïnikov Evropeïskoï chasti SSSR. Izdatel'stvo Akademii Nauk Belaruskoï SSR, Minsk, 532 pp.

Tønsberg T. 1992. The sorediate and isidiate, corticolous, crustose lichens in Norway. Sommerfeltia 14: 1331.

Tønsberg T. 1999. Lichenes Isidiosi et Sorediosi Crustacei Exsiccati. Schedae to Fascicle 2 (Nos 26 50): 1 10. Bergen, Norway.

Tønsberg T., Türk R., Hofmann P. 2001. Notes on the lichen flora of Tyrol (Austria). Nova Hedwigia 72: 487497. 
Wirth V. 1997. Additional lichen records from New Zealand 21. Candelariella coralliza, Lepraria ebur nea, Racodium rupestre, Rinodina olivaceobrunnea, Rinodina pyrina and Trapeliopsis flexuosa. Aus tralasian Lichenological Newsletter 40: 1113.

\section{Materiały do bioty porostów Białorusi}

\section{Streszczenie}

Biota porostów Europy Środkowej i Środkowo Wschodniej jest stosunkowo dobrze po znana, choć pewne jej grupy są ciągle słabo zbadane. Dotyczy to zwłaszcza sorediowanych, zwykle płonnych porostów skorupiastych oraz grzybów naporostowych. W wyniku tego wiele gatunków częstych, a nawet pospolitych w innych obszarach Europy, nie zostało dotychczas odnotowanych w poszczególnych krajach tej części kontynentu.

Celem niniejszej pracy jest uzupełnienie danych o porostach sorediowanych Białorusi. Spośród 12. prezentowanych taksonów, sześć gatunków porostów (Cliostomum leprosum, $\mathrm{Fel}$ lhanera gyrophorica, Lecanora thysanophora, Lepraria eburnea, L. jackii, L. neglecta) oraz je den grzyb naporostowy (Tremella hypogymniae) zostały podane po raz pierwszy dla Białorusi. Ponadto wykazano nowe stanowiska dla niedawno odnotowanych Lepraria elobata i L. incana, potwierdzonych za pomocą chromatografii cienkowarstwowej (por. Czyżewska i Kukwa 2005). Gatunki te, jak i pozostali przedstawiciele rodzaju Lepraria są najprawdopodobniej bardzo częstymi składnikami ekosystemów na terenie Białorusi. Ponadto potwierdzono za pomocą analizy wtórnych metabolitów porostowych występowanie Chrysothrix candelaris, Lo xospora elatina i Pertusaria coronata. Okazy Ch. candelaris reprezentują chemotyp 1 (stwier dzono kwas pinastrowy). Według niektórych badaczy (por. Kalb 2001) ta rasa chemiczna może reprezentować gatunek jeszcze nieopisany dla nauki; wymaga to jednak dalszych badań, w tym także molekularnych. Dla Cliostomum leprosum podano także stanowiska z Polski, któ re nie były nigdy wcześniej publikowane, pomimo odnotowania tego taksonu w kraju (por. Fałtynowicz 2003). 
